\section{Muhammed Haron}

Muhammed Haron is an Associate Professor in the Department of Theology \& Religious Studies, University of Botswana and Associate Researcher in the Department of Religion Studies, University of Johannesburg.

E-mail: haronm@mopipi.ub.bw

\section{Review essay \\ Achmat Davids places the Cape Muslims on the South African linguistic map}

\title{
Achmat Davids places the Cape Muslims on the South African linguistic map
}

South Africa's Cape Muslim religious leaders creatively contributed towards the formation of Afrikaans linguistics, an issue that the South African academia seemed to have ignored and overlooked. By the beginning of the $20^{\text {th }}$ century, the literary output of these religious leaders developed to form a unique genre of literature; a genre that is popularly referred to as "ArabicAfrikaans" within the South African linguistic circles. Achmat Davids (1939-98), who may be regarded as the doyen of "Cape Islamic Studies," was among a handful of scholars who devoted much of his time to study carefully this type of literature. As a consequence of his labour, he produced one of the most significant contemporary works in South African linguistics. This review essay reflects upon the importance of Davids' path-breaking and invaluable study, which was recently co-edited by Hein Willemse and Suleman E. Dangor. Keywords: Achmat Davids (1939-98), Afrikaans linguistics, Arabic-Afrikaans, Cape Muslims, South African linguistics, South African social history.

\section{The Afrikaans of the Cape Muslims.}

Achmat Davids. Eds. Hein Willemse and Suleman E. Dangor. Pretoria: Protea, 2011. 318 pp. ISBN 978-1-86919-236-5.

\section{Introduction: Davids' research output}

Cape Muslims are deeply indebted to Achmat Davids (1939-98) for having excavated several aspects of their rich social history (Jeppie). He wrote, for example, the fairly insightful Mosques of the Bo-Kaap: A Social History of Islam at the Cape (1980); a work that offered a detailed view of how the forbears of this Muslim community contributed in making the upper portion of Cape Town - popularly referred to as the Bo-Kaapa vibrant and lively area. Apart from this important work, Davids also penned his informative The History of the Tana Baru (1985) as well as a wide selection of some of his salient writings that were inserted in Pages from Cape Muslim History (1994) that he coauthored with Yusuf da Costa.

Davids' plethora of articles, which were written between the mid 1970s and the late 1990s, featured in a number of non-peer reviewed magazines such as Boorhaanul Islam Newsletter (Cape Town) and Arabic Studies (University of Durban-Westville) and 
many peer-reviewed journals such as Kronos: A History of the Cape (University of the Western Cape), Journal for Islamic Studies (Rand Afrikaans University/University of Cape Town) and Matatu: Journal of African Culture and Society (Amsterdam). In the mentioned and other publications Davids demonstrated to what extent the Cape Muslims left behind a thriving legacy, one that recorded their inputs to inter alia the Cape's delicious cuisine, the clothing sector and the extensive building industry.

From the long list of publications, Davids' most significant research pieces focused on the Cape Muslims' linguistic tradition. This short essay is essentially a review of Davids' thesis that was edited by Hein Willemse (University of Pretoria) and Suleman E. Dangor (University of KwaZulu-Natal). Let us, however, place Davids' work on Arabic-Afrikaans within a linguistic context so that we may have a broader view of where his invaluable and impressive contribution fits into the socio-linguistic scheme of South African studies.

\section{Locating Arabic-Afrikaans in the linguistic context}

By the time he successfully completed his MA thesis in 1991 at the University of Natal, now the University of KwaZulu-Natal (UKZN) on Arabic-Afrikaans, a thesis that was transformed by Willemse with the assistance of Dangor into this book under review, Davids had written a few articles that dealt with this topic. These appeared in the South African Journal of Linguistics and Lexikos: Journal of Lexicography (University of Stellenbosch). And by then he built on the works of two prodigious scholars, namely Adrianus van Selms (University of Pretoria) and Hans Kähler (Hamburg); both of them had studied selected Arabic-Afrikaans texts in some detail. Van Selms authored, among others, Arabies-Afrikaans Studies 1: 'n Tweetalige kategismus (1951) and Kähler produced Studien über Kultur: Die Sprache und der Arabisch-Afrikaanse Literatur der KapMalaien (1971). And it was exactly twenty years after Kähler's text that Davids finalized his thesis on this important subject. Although there is little doubt that the two mentioned scholars in addition to Pieter Muller, Ernst Frederick Kotze, Marius Valkhoff and F. A. Ponelis churned out invaluable linguistic studies related to Arabic-Afrikaans, it was Davids' priceless research on Arabic-Afrikaans that changed the linguistic debate and one that stirred scholars to revisit and reflect upon how the Afrikaans language evolved and developed since the $18^{\text {th }}$ century.

Besides narrating the general history of the Cape Muslims, Davids' research turned its attention to the way this community's forebears constructed and linguistically engineered the language that they employed in their homes and in the marketplace during the $19^{\text {th }}$ and (early) $20^{\text {th }}$ centuries respectively. Even though this linguistic story was already captured in the works of van Selms and others, it only seemed to have dawned upon the Cape Muslim community after Davids' important articles appeared in the mentioned journals to what degree Muslims had had a visible hand 
in the development of the Afrikaans language. Soon after this awakening in the 1990s, the Afrikaans speaking community in general and the Cape Muslims in particular came to gradually realise through Davids' handsome research outputs the nature and extent of this contribution.

\section{Cape Muslims' Afrikaans: Davids' research project}

But despite Davids' significant linguistic intervention at a critical period in South Africa' socio-political history, a time when democratic changes were underway, it was indeed sad to record that there was no one who followed in Davids' footsteps to further explore this area of linguistic studies; an area that may be viewed as a new sub-discipline of the Afrikaans language. Very recently it was observed that scholars such as Gerald Stell (University of Leuven) and Kees Versteeg (Catholic University of Nijmegen) have shown an interest by exploring different dimensions of the field; a development that Davids would have welcomed if he had still been around. What was disheartening — to say the least—was that even though Davids' thesis sparked public interest at the time when he completed it, it remained out of the public eye for two decades!

As far as we recall, Davids was urged to consider transforming the thesis into a book but for some uncanny reason these early efforts came to naught. Another attempt was made at the request of Willemse, who was a specialist in the Afrikaans language and literature at the University of the Western Cape before shifting to the University of Pretoria where he took up a professorial post in the Afrikaans department. Willemse, who had a meeting with Davids shortly before his death during September 1998, expressed the need to have the thesis edited and published. Whilst the idea was accepted and endorsed by Davids, death overtook him. As a result, Willemse took it upon himself from that moment onwards to see this project through. After an agreement was struck with Kariema Davids-Jacobs (Davids' former wife who is in charge of his estate) and the authorities at UKZN, Willemse eagerly started to plan the editing process.

Since Willemse was not well versed with the reading of the Arabic script, he called upon the expertise of Dangor, who was Professor of Islamic Studies at the UKZN (until the end of 2010), to assist in this intimidating and daunting task. Both Willemse and Dangor-like many other editors—-had to take into account numerous challenging issues prior to agreeing on the best process that would transform this project into a published text. These they listed and briefly explained in their "afterword." In spite of the hurdles of translating, transliterating and a host of other technical aspects that go along with the editorial process, the two editors succeeded in producing a long over-due, well-argued and timely text. Prior to assessing the editorial process, let us reflect upon edited text's structure and contents. 


\section{The transformed text: its structure}

To begin with, Willemse and Dangor—as the bona fide editors—generally remained faithful to the format and structure of Davids' original thesis. Davids divided his thesis into six chapters with the introduction as the first chapter. In his opening chapter Davids introduced the thesis by "Setting the scene and defining the concepts" (15-32). Herein Davids explained the purpose of his research project and clarified critical concepts and phrases such as "Arabic-Afrikaans," and he also explained the reasons for having described the formation of Arabic-Afrikaans as an 'innovative orthographic engineering' process. Davids acknowledged that it was Adrianus van Selms, the Professor of Semitics at the University of Pretoria, who coined the term "Arabic-Afrikaans."

Once having explored the field in some detail, Davids agreed with van Selms' descriptive label; a label that Davids regarded as all-encompassing and appropriate one. In spite of this, there are others such as University of the Western Cape's Prof Yasien Mohamed who felt in his personal correspondence to us that this term is not an apt one and that "Jawi-Afrikaans" should have been considered as an alternative term. He seems to argue along the same lines as some Malaysian scholars do; they termed this form of writing as Jawi-Melayu (Davids 58). Nevertheless, in spite of these differences of opinion the van Selms coined term has generally been accepted and has remained popular until this very day. The term essentially refers to those Afrikaans manuscripts and lithographic texts that were written in the Arabic script by Cape Muslim religious scholars between 1815 and 1915 (and beyond). And in the process of preparing these manuscripts and texts, Davids cogently argued that they undertook a process of what he termed "innovative orthographic engineering." This involved amongst others the way these religious scholars managed to create neologisms and other linguistic forms.

Subsequent to satisfactorily clarifying these concepts, Davids discussed "The world the Cape slaves made" in the second chapter (33-88). The chapter discoursed about the emergence of the culture and the literary traditions of the Cape Muslim community. In this chapter he, inter alia, addressed the different ethnic identities as well as their linguistic and literary traditions that contributed to the community's emergence. This fairly detailed and informative chapter laid the groundwork for the third chapter which reflected on "the Afrikaans literature of the Cape Muslims: 1845-1915" (89-150). Herein he listed the inventories of the manuscripts in the Arabic as well as Roman script. Davids outlined the stages of this unique literary tradition and made reference to the pre and post-Bayān al-Dinn scripts. And he also dwelled on the works of specific religious figures such as Ghatieb Magmoed. The description and analyses of the works of these scholars paved the way for Davids to deal with "Afrikaans writing and spelling in Arabic script" in the fourth chapter (151-200). In this chapter Davids revealed some fascinating aspects of the Cape Muslim religious leadership's 
creative spirit. They undertook what he termed the "innovative orthographic engineering" process with regards to the Arabic script. Among others, Davids conversed about the Arabic-Afrikaans vocalic system, the formation of certain sounds and the construction of Afrikaans diphthongs. On the whole, his arguments underscored and demonstrated the innovative spirit that was prevalent among the numerous religious personalities who prepared and penned their texts for their prospective audience and subsequent generation of students.

The penultimate chapter turned its focus to "Writing Arabic and Arabic-Afrikaans in the Roman script" (207-56). In the first section of this chapter Davids addressed the problematic issue of transliteration that are encountered internationally. This system was an interesting exercise because of the inherent difficulties when undertaking this process. Davids pointed out the problems of employing the international system such as the one that had been proposed and followed by the International Journal of Middle Eastern Studies (IJMES), a well-respected North American peer reviewed journal. Davids thus recommended or rather proposed a standard system that may be applicable to the South African context. In order to show its effectiveness and applicability he extracted sample pages from some of the famous manuscripts that had circulated at the Cape and indulged in the transliterating exercise. Whilst this was a very taxing task, Davids encountered a situation in which the exercise of transliterating certain words was not that easy; he realised that it depended upon many factors; one of these is the way the heterogeneous Cape Muslims pronounced and wrote certain letters and words not encountered in the Afrikaans language and another is how these should be rendered when transliterating them.

After having closely combed through Davids' well set out and argued thesis, it may be stated that he was extremely familiar with the various Arabic-Afrikaans manuscripts and their respective authors. Apart from his familiarity, Davids also managed to become acquainted with the science of linguistics before he examined some of the manuscripts. Davids' mastery comes to the fore in the manner he presented his arguments and the way he challenged the views and arguments of those, namely van Selms, Ponelis and Kähler, who had authoritatively written on the subject. Before we pick three examples to show why Davids was in command of the area that he tackled, brief mention should also be made of the fact that Davids also carelessly slipped upped and erred. There were times when Davids incorrectly translated or transliterated a title or a sentence without making sure that it conveyed the correct meaning. In the one recurring example, the title of Imam Abdul Malik Kahaar's text was rendered as Tuhfat ul-Ahwām. If we ventured to translate this title, based of course on the Davids' transliteration, it would convey a different meaning, namely 'a gift of crowns [?].' Unfortunately the editors seemed to have overlooked this and nor did they offer a translation in a footnote on the particular page where it appeared for the first time; they basically left the title as is (124-27). In any case, if the title had been 
perfectly transliterated as it should have, namely Tuhfat ul-'Awāmm (A gift for the [general] populace-refer to Hans Wehr's Arabic-English Dictionary [641]), then it would, to some degree, have reflected the text's objective. At this point let us not dwell too much on this specific shortcoming in Davids' thesis/edited text but let us return to highlighting the three examples that illustrates his critical assessment of others who wrote on the subject. The first example is taken from chapter 3 in which Davids critically questioned van Selms', who had somewhat mastered the field and had written numerous texts, incorrect identification of a particular Arabic-Afrikaans manuscript. Davids argued that if van Selms had been acutely aware of the different manuscripts' contents and had been familiar with the writing of their authors, then he (van Selms) would not have committed the errors in his transcription and assessment (103). In the second example Davids critiqued van Selms for not having applied his mind to the fact that vocalisms played a crucial role in the reading of Arabic by nonArab communities. Since this was the case van Selms' phonetic transcriptions of the specific manuscript were also faulty (158). And in the third example, he responded to Ponelis' study; the latter had erred when he misread the Arabic-Afrikaans lettering symbols (214). Whilst Davids severely reacted to the unnecessary errors that these and other scholars made, he was also generally kind towards them. Davids balanced his assessment and was somewhat gracious towards them for having made important linguistic inputs on the subject. On the whole, Davids' text demonstrated the amount of knowledge that he possessed and the confidence he exuded when he dealt with this neglected linguistic area.

Davids concluded his text by offering his observations and comments in the final chapter (257-63). And in the annexure the editors included M. C. J. van Rensburg's essay on the "study of Afrikaans over a period of 100 years (circa 1815-1915)" and their "afterword." Thereafter they inserted the bibliography of primary and secondary works (304-11) and a useful register (312-18) of terms, titles and personalities that appeared throughout the edited text. As a matter of information, the first few pages of the text contained an acknowledgment (11-12) and a preface (13-14) by Davids' supervisor, namely Theodorus du Plessis. And before going any further, let us commend the editors for choosing Angas' famous and oft-circulated painting, Malay School Boys Learning to Read the Koran (1849), for the book's cover. I. D. du Plessis also inserted a print of this painting in his book The Cape Malays (1944). It is indeed a very appropriate choice that captures what The Afrikaans of the Cape Muslims is all about.

\section{The editing process: an intimidating task}

As already mentioned in an early section, the editors pointed out in their "afterword" (300-03) the reasons for editing Davids' thesis; a work that was a pioneering effort and in the informed opinion of the editors "a path-breaking study." Since Davids' research 
output produced key findings, the editors felt the need to have it edited and circulated to a wider reading audience. Despite the noble intentions to have had it edited soon after Davids' death, the main editor (i.e. Willemse) encountered numerous obstacles along the way before the edited thesis eventually reached the Protea publishing house. Since the editors advised in their "afterword" the researchers, who might wish to query and corroborate certain editorial changes, to read the original manuscript that is housed at UKZN's Howard library this reviewer was among those who decided to do that. Bearing this in mind, the issues raised in this section thus made constant reference to both texts (i.e. the thesis and the edited text) where necessary.

When the editors embarked on the editing process they were faced by a variety of issues; many of these issues were difficult to ignore when transforming an unpublished manuscript such as a thesis into an edited published text such as a book. One of the first important editorial interventions that the editors had to make was to choose a referencing system that was "more reader-friendly and (one that) suits this type of historiographical and linguistic text" (in Davids 302). Since they considered the Harvard referencing system, the one that Davids used for the thesis, not appropriate for this text, they selected the Chicago footnote (fn) style of reference; a referencing system that they were fairly comfortable with and one that seems to be popular in certain publishing sectors.

Having settled for a user-friendly referencing style, the editors then had to confront a list of editorial matters such as structural amendments, grammatical constructions and spelling conventions. Since these were among the short list of editorial matters that occupied them in this demanding venture, they had to act prudently and judiciously so as not to disturb the flow of Davids' arguments or change the intention of the sentence construction. When we closely compare the two texts, it is obvious that the editors did not liberally use their position to make arbitrary changes; what comes across quite clearly was that they made a concerted effort "to keep the spirit and intention of the original manuscript" (300) and only occasionally were forced to bring about amendments where the sentence construction of Davids was clumsy.

Perhaps it would be best at this juncture for us to extract samples that illustrate how they managed to deal with and overcome each of the challenges. But before doing so, it should also be highlighted that as we browsed through the thesis and the edited text, there were inaccuracies that Davids made and that were overlooked by the editors, and there were mistakes that the editors made and that should have been corrected. In the following section, we shall refer to the errors and rectify them. Let us begin with the structural amendments that the editors faced from the outset.

\section{Structure}

One of the first issues that the editors grappled with was some of Davids' awkward 
formulation of sentences. As a consequence of the presence of these constructions in different parts of the thesis, the editors made the necessary amendments and adjustments without going against Davids' intentions and thus retaining the original meaning. Herewith find a few examples: (a) Compare chapter 1's paragraphs on p. 19 of the edited text (hereafter ET) with those that appear on pp. 5 and 6 of the thesis (hereafter T), and do the same with the paragraphs on p. 29 of ET with those that appear on pp. 18-19 in T. In both cases, where the passage formed part of the body of the text in T the editors took the liberty of inserting it as a footnote (ET $55 \mathrm{fn} .80$ ). (b) The editors transferred Davids' long-winded sentence, "Except for the letters..." to a footnote (ET $86 \mathrm{fn} .182$ ), and (c) they rephrased the sentence that appeared in the first paragraph (T 120; ET 121) instead of "Many of them, in terms of content, were pitched at children, and therefore, deal with the basics of Islam," they changed it to: "Many were pitched at children and therefore dealt with the basics of Islam." (d) They changed the format by dispensing with the data that were in a table as was the case in $\mathrm{T}(162)$ and weaved the information into the body of ET (155). And (e) they shifted a portion of the text into a footnote; see and compare p. 169 in T with fn 29 p. 163 in ET.

\section{Grammar}

The editors noted that Davids did not, at times, observe the grammatical rules as expected; although there were not many, the editors amended the sentences accordingly. For example, Davids wrote: "This could be attributed to the fact that their reading audience could not read Arabic graphic script..." (T 10) and the editors replaced the first 'could' with 'can' (ET 23). And in another example, Davids' sentence read: "... if the (letter) ra were silent ..." instead of "... if the (letter) ra is silent ..." (ET $162 ; \mathrm{T} 168)$.

\section{Spelling}

The issue of spelling was quite a challenging one for the editors. On the one hand, they had to conform to a standard format and, on the other hand, they had to consider the format that took into account three (and more) different languages. They stated in their "afterword" that, "Where Davids's spelling or translations were obviously incorrect or the result of typographical errors, we have corrected them 'silently'. For the fastidious Arabic reader several names may have been transliterated wrongly in the original, e.g. 'Abd al-Rahim is transliterated as Abdurahim [...] In these cases we have retained Davids's rendition of these names but on their first occurrance (sic) we have inserted the contemporary transliteration in square brackets" (Davids 2011: 301). The editors mentioned that they harmonised the spelling where Davids followed different spelling conventions.

We generally concur with the editors' approach in dealing with the spelling conventions that Davids adopted with regards to the names of the persons and places. 
Perhaps we should provide two specific examples that illustrate the inherent problems with the spelling conventions. Let us take the simple title "sheikh" as it appears in the thesis and the edited text. Whilst the word has been accepted in English, the Oxford dictionary recognizes another form of spelling and that is "shaikh;" even though it is an uncommon and an unpopular form it has been approved by its compilers (Hornby 1086). Should we observe the rules of transliteration the correct spelling would be "shaykh" and not "sheikh."

The other example that we want to refer to is the title of Abu Bakr Effendi's famous Arabic-Afrikaans theological text. Davids presented the transliterated title as one complete word, namely Bayānuddin (T 113-23), and the editors chose a slightly different format by correctly presenting it as a phrase, namely Bayān al-Dīn (ET 115-21). Even though both are generally acceptable ways of spelling or transliterating the title, the proper method, if we follow the United Nations Romanization system that differs slightly from IJMES, should be Bayān ud-Dinn (UNGEGN Working Group). In this instance the definite article $a l$ is assimilated with the first consonant of the word $D i n$ and it is not written separately according to the method followed by the editors and not completely assimilated as in Davids' example. Apart from observing these writing conventions, we have to take into account how the individual is going to read the phrase. An Afrikaans reader who is oblivious of the prevailing transliteration systems might venture to transliterate it as follows: Bajaan Oedien. And related to this, we note that Allie transliterated the title differently: Bayān-uddinn. What all of this demonstrates is that speakers, researchers and editors will always find this a major challenge.

From this we can deduce that since the editors were fully aware of the problems associated with the spelling and the transliteration of names and titles, they tried to look for the best option in resolving them within the context. Having cleared themselves regarding this needling issue, let us make reference to one example here since more samples of transliteration will come up later: Davids transliterated the title of a famous East African poem as: Mawlid-Barzanzi; the editors rectified the spelling and wrote it as: Maulid Barzanji (ET 38; T 29). That noted, let us make reference to a few simple typographical mistakes that the editors corrected: '44 yrears' (T 35; ET 46), 'arqued' (T 39), 'excempted' (ET 49), 'almanac' (ET 68 fn. 127; T 62), and 'fiqa' (ET 74; T 69); even though they picked up these corrections, they seemed to have overlooked the incorrect spelling of 'aaarme' (ET 229 line 2; T 255).

\section{Translation}

The question of translation like transliteration was a challenging issue. Here we shall only give four examples: Davids translated the title: "A message on behaviour in burial grounds" (T 90) instead of "A [Comprehensive] Treatise involving [correct behaviour] when visiting graves" (ET 91, 93), "Guidance in accordance with the way of the Wahhabis" (T 106) instead of "Guidance to the Correct Method according to the 
Wahhabis" (ET 108), and "Book of Knowledge of Inheritance" (T 138) instead of "Book on the Knowledge of Religious Duties" (ET 136), and "A book on moral behaviour for children (T 105) instead of "A Reading Book for the Pupils of the Habibiyya Madrasah" (ET 107). In the last mentioned case, Davids not only incorrectly translated the title but he also neglected to give the full title; the editors picked this up and rectified it.

\section{Transliteration}

As already indicated earlier, one of the most challenging issues that researchers and particularly editors encounter in manuscripts such as this is the question of transliteration. In this case, the editors were challenged by the system that Davids conformed to in his thesis and the one that they queried and considered appropriate (ET 300). Whilst Davids was acutely aware of available international systems that assist one in the process of the transliteration of words from Arabic, Persian and Urdu to the Roman script (T 14-17; ET 26-28), he did not strictly conform to the international system. He devised a method that was close to conveying the exact sound of the letter and words from Arabic-Afrikaans into the Roman script.

Let us refer to a select few examples: Davids transliterated (a) Muschat-al-Masabah (T 105) instead of Mishkät al-Masäbïh (ET 107), and (b) Jam-i-tool Oloma (T 101) instead of Jami'at al-'Ulama' (ET 104). And in one instance (c) the editors stated that Davids transliterated the title of one of Sheikh Ismail Ganief's work as Al Mukaddioatu Uadramia (ET 49 fn. 61). After crosschecking it was observed that this was not the case. Davids, in fact, transliterated it as Al Mukaddimatu Hadramia and they amended it slightly as al-Muqaddimat al-Hadramiyyah (T 306; ET 136). And (d) Davids, who relied on Kähler, was convinced that Imam Abdul Malik Kahaar's text was transliterated as Tuhfatu'lahwäm (ET 126). The editors went along with this (ET 124-126) but altered the transliteration slightly to Tuhfat ul-Ahwäm. Upon closer inspection the transliteration should be Tuhfat ul-Awāmm (ET 248).

And there were examples that the editors should have rendered according to the international convention but, for some reason, left them unaltered: Al-Shilmitāni (T 122; ET 121) [or Al-Thilmisāni in Register (ET 312)] should be Al-Tilmisāni (T 75 ch. 2 fn. 144; ET 121 ch. 3 fn. 92), id häm (ET 163) should be id ghäm, shard' (ET 240 fn.278 line 8) should be shart, and moetakhiel (ET 94 line 15; ET $139 \mathrm{fn}$. 141) should be mustahìl; the latter was, however, reflected in footnote 22 on p. 94 in ET but not rectified on p. 139 by the editors. Since the issue of transliteration is inextricably tied to the Arabic scripted texts, we wish to bring the reader's attention to the problems the editors encountered when they reproduced some of the lithographic texts and when attempts were made to retype some of the examples in the Arabic script.

\section{Arabic texts}

The samples of lithographic material that the editors used for this publication were 
regrettably unclear (ET 97-98). Besides having been let down on this front, they were also let down by the software package that the publishers used. The letters of each of the Arabic words and sentences, which were retyped to emphasize particular linguistic conventions, appeared disconnected from the other and it gave the impression that the text was poorly edited. The letters that appear separate are supposed to have been connected to one another so as to formulate the complete word or phrase. Even though this was not as a result of poor editing, it came across like that and there was nothing the editors could do after it was published (ET 156, ET 179).

Unfortunately for the editors, they were further disappointed when the translation of the Arabic-Afrikaans text of Abu Layth as-Samarqandi (i.e. Masá'il) did not appear alongside it in Annexure 2 (ET 273-86); the short translation piece was mistakenly slotted in under Annexure 3 (ET 290-92); a different annexure altogether!

Even Annexure 1, which supposed to contain extracts from Abu Bakr Effendi's Bayān al-Dinn, consisted of Kitab al-Zakät that was written by his son, Hisham Effendi (ET 264-70) and the same goes for the translation that appears in that annexure (ET 271-72).

\section{Other}

In addition to the above, we came across a few other entries that the editors should have crosschecked instead of having assumed that there were no data available or that the information supplied by Davids was correct.

The editors were unable to identify the following entry: 'Kuller, [no publication particulars], 1960' (ET $18 \mathrm{fn}$. 9). But after careful reflection, we were able to make a connection between "Muller" and "Kuller;" the correct entry was "Muller," in fact, and not "Kuller." The relevant bibliographical details were available in list provided by Davids; they were: Muller, P. J. "Afrikaanse geskrifte in Arabiese karakters", Quarterly Bulletin of the South African Library 15, 1960 (T 315; ET 309). And speaking of identification, it was noted that Davids referred to an unidentified scholar by the name of 'Diringer' (ET 152; T 158); the editors were not able to provide any additional material on this individual. The same argument goes for an unknown Shayg Gasabullah (transliterated as: Sheikh Hisb Allâh) to whom Davids referred to in his study (ET 101 fn. 41; T 98). On a related issue, the editors seemed to have been oblivious of the fact that Ebrahim Davids whom Achmat Davids interviewed was none other than the author's elder brother; they thus did not mention it at all (ET 142 fn. 150; T 145).

Davids mistakenly thought that Rochlin's published article appeared in 1959; the date should be 1933 (ET 46 fn. 54). Since the editors did not double check, they repeated Davids' mistake in ET (36) as well as in the bibliographical list (ET 316).

P.B.U.H, which means "peace be upon him," should have inserted next to the word "Prophet" and not after the word "Islam," as noted on p. 28 in the thesis and edited text (ET 38). 
The editors retained Davids' use of the word "Malaysian" in their text. This is a term that was only coined at the time of Malaysia's independence and not before. In our view the editors should have provided a brief comment of this term in a footnote (T 46; ET 56-58).

For some reason, Davids used the word "sect" interchangeably with "school of Ahli Sunni wal Jama' ah" (T 121); in this instance, the editors should have commented and clarified the term in a footnote (ET 120) since the two terms are not the same in meaning.

We are of the opinion that the editors should have commented in a footnote on the word "say-rie" (ET 137 para 3; T 139). The word as it stands is a corruption of the Arabic word, which is pronounced as "sayyid". It, which essentially means "a gentleman or a master," is an honorific title given to someone who is a descendent of Prophet Muhammad (Wehr 440).

Davids used the word "moola" (T 143; ET 140), also spelt as "mullah" or "moulvi" or "mawlana", as a title attributed to Hisham Effendi who was of Turkish descent. Being an Urdu word, we found it intriguing that Davids employed this word, and not commented upon by the editors. This word is, in fact, a title generally given to a person who graduated from a Muslim theological seminary in South Asia. And it is a title that is equivalent to the designation "Sheikh," a person who graduated from a Middle Eastern Muslim theological institution.

Now that we have covered a fair selection of issues that the editors addressed as well as a few that they failed to notice, we want to offer thoughts on how this text could have been further transformed and enriched. Our argument is based upon the fact that since this is the only edited text of its kind on this subject the editors could have used the opportunity to embellish and update the literature on the subject. In other words, they could have added and footnoted material that became available during the past two decades (i.e. from the time Davids completed his thesis in 1991 until 2010). In our view, if they had adopted this policy then Davids' edited text would have stood out as a unique, up-to-date volume on a sorely neglected topic in South African linguistic studies.

Since we appear to be quite convinced about this, let us reflect on a random selection of material that have been produced over the past two decades and that could have been included in this edited text. Since Davids devoted part of his study to Abu Bakr Effendi's contribution, the editors could have drawn material from the Centre for Islamic Studies at Rand Afrikaans University (RAU), which coincidently underwent a name change and presently known as the University of Johannesburg (UJ), where some interesting research projects were completed at the postgraduate level and that could have been inserted in the footnotes as well as the bibliographical list. Here N. Allie's "The Impact of Bayān-uddin, the al-Riyad al-Bädi'ah and the alHadramiyah on the Cape Muslim Community" (1997), S. Argun's "The Life and Contri- 
bution of the Osmanli scholar, Abu Bakr Effendi: Towards Islamic Thought and Culture in South Africa" (2000), and Serhat Orakçi's "A Historical Analysis of the Emerging Links Between the Ottoman Empire and South Africa between 1861-1923" (2007) come to mind.

The editors could have included Y. da Costa and A. Davids' jointly edited Pages From Cape Muslim History (1994) and M.van Bruinessen's "A Nineteenth-century Kurdish scholar in South Africa;" (2000). And they could have added to these, M. Sahin's "Formation of Cape Colonial Community and the Ottoman Turkish Existence in South Africa," (2006) and Ahmet Uçar's Unforgotten Legacy: Ottomans in South Africa (2007). Whilst most of these texts made specific reference to the Ottoman Turk influence at the Cape and touched upon Abu Bakr Effendi's Bayān al-Dīn, we are convinced that researchers would like to have seen these in the footnotes for they would have shed further light on the late $19^{\text {th }}$ century socio-linguistic and historic-theological developments; and this Davids would have welcomed.

Since the death of Davids in 1998, a few articles were published that either added new dimensions to what had been written up until then or complemented them. It would, for example, have been useful to have footnoted Muhammed Haron's "Samarqand-Cape Town Connection: Revisiting a 10th Century Theological Text," (1999), Ebrahim Moosa's "Arabic-Afrikaans" (2004), Muhammed Haron's 'The Preservation and Study of South Africa Ajami Manuscripts" (2001/2002), Gerald Stell's From Kitaab Hollandsch to Kitaab-Afrikaans: The Evolution of a Non-white Literary Variety [1856-1940] (2007), G. Stell, X. Luffin and M. Rakiep's “Religious and secular Cape Malay Afrikaans. Literary varieties used by Shaykh Hanif Edwards (1906-1958)" (2007) and Suleman E. Dangor's "Arabic-Afrikaans Literature at the Cape" (2008). Even though some of them might have repeated what Davids had already recorded, there are the works such as the "Samarqand-Cape Town Connection: Revisiting a 10th Century Theological Text" and From Kitaab Hollandsch to Kitaab-Afrikaans that have added new insights to the Arabic-Afrikaans theological and linguistic debates respectively.

\section{Towards a conclusion}

When reflecting upon Davids' significant thesis, there is ample evidence that he had contributed in a substantial manner to both the theological and linguistic debates respectively. This edited text as well as his earlier writings had made an input to the understanding of the theological issues at the Cape and they prised open the intense discussions about the Cape Muslims' inputs to the development of the Afrikaans language. Notwithstanding some of Davids' mistakes and apart from the two editors' oversights regarding a few minor errors that were mentioned in the previous section, this edited text demonstrated that it was a meritorious research project that we are all indebted to in more ways than one. 
We are indebted to Davids for not only making us conscious of the Cape Muslims' contributions to Afrikaans but for bringing to our attention the legacy that our forebears left behind; a legacy that we can all relate to and be proud of. The research project has to some extent lay to rest some of the earlier problematic linguistic issues. And Davids, like many other avid researchers, set a few guidelines for future researchers and this clearly indicates Davids' foresight and interest in this field.

With these remarks, we can say that the editors did a wonderful and marvellous job in once again reminding us of Davids' invaluable contribution to the South African society in general and the linguistic community in particular. Whilst this is an edited text that should be prescribed in all courses in linguistics and literature at Southern African universities, it should also be of interest to social historians.

\section{Works Cited}

Arabic Studies (U of Durban-Westville).

Boorhaanul Islam Newsletter (Cape Town).

International Journal of Middle Eastern Studies (MESA, Texas).

Journal for Islamic Studies (Rand Afrikaans U / U of Cape Town).

Kronos: A History of the Cape (U of the Western Cape).

Lexikos: Journal of Lexicography (U of Stellenbosch).

Matatu: Journal of African Culture and Society (Amsterdam).

South African Journal of Linguistics.

Allie, N. "The Impact of Bayān-uddinn, the al-Riyad al-Bādi'ah and the al-Hadramiyah on the Cape Muslim Community." BA Honours Rand Afrikaans U, 1997.

Argun, S. "The Life and Contribution of the Osmanli scholar, Abu Bakr Effendi: Towards Islamic Thought and Culture in South Africa." MA thesis Rand Afrikaans U, 2000.

Da Costa, Yusuf and Achmat Davids. Pages From Cape Muslim History. Pietermaritzburg: Shooter \& Shuter, 1994.

Dangor, Suleman E. "Arabic-Afrikaans Literature at the Cape." Tydskrif vir Letterkunde 45.1 (2008): 123-32.

Davids, Achmat. Mosques of the Bo-Kaap: A Social History of Islam at the Cape. Cape Town: The South African Institute of Arabic and Islamic Research, 1980.

-. The History of the Tana Baru: The Case for the Preservation of the Muslim Cemetery at the Top of Longmarket Street. Cape Town: Tana Baru Preservation Committee, 1985.

Du Plessis, I. D. The Cape Malays. $2^{\text {nd }}$ ed. Cape Town: Maskew Miller, 1947.

Haron, Muhammed. "Samarqand-Cape Town Connection: Revisiting a 10th century theological text." The Arabist: Budapest Studies in Arabic 21/22 (1999): 73-88.

- "The Preservation and Study of South African Ajami Manuscripts." South African Archives Journal 42 (2001/2002): 53-60 .

Hornby, A. S. Oxford Advanced Learner's Dictionary. Ed. Sally Wehmeier. $6^{\text {th }}$ ed. Oxford: Oxford UP, 2001. Jeppie, Shamil. "Achmat Davids (1939-1998)." Journal for Islamic Studies 18/19 (1999): 150-53.

Kähler, Hans. Studien über Kultur: Die Sprache und die Arabisch-Afrikaanse Literatur der Kap-Malaien. Berlin: Dietrich Reimer, 1971.

Mohamed, Yasien. Personal communication, June 2011.

Moosa, Ebrahim. “Arabic-Afrikaans." Encyclopaedia of Islam. Leiden: Brill, 2004.

Orakçi, Serhat. "A Historical Analysis of the Emerging Links Between the Ottoman Empire and South Africa between 1861-1923." MA thesis U of Johannesburg, 2007. 
UNGEGN Working Group on Romanization Systems. "Report on the Current Status of United Nations Romanization Systems for Geographical Names. Arabic." January 2003. 4 Nov. 2011. < http:/ /www.eki.ee/wgrs/rom1_ar.pdf>.

Sahin, M. "Formation of Cape Colonial Community and the Ottoman Turkish Existence in South Africa." Pakistan Journal of Social Science 3.9 (2006): 1129-37.

Stell, Gerald. From Kitaab Hollandsch to Kitaab-Afrikaans: The Evolution of a Non-white Literary Variety [1856-1940]. Stellenbosch Papers in Linguistics 37 (2007): 89-127.

Stell, Gerald, Xavier Luffin, and Muttaqin Rakiep. "Religious and Secular Cape Malay Afrikaans. Literary Varieties used by Shaykh Hanif Edwards (1906-1958)." Bijdragen tot de Taal-, Land- en Volkenkunde 163 (2007): 319-53.

Uçar, Ahmet. Unforgotten Legacy: Ottomans in South Africa. Ensenlar: ÇAMLICA, 2007.

Van Bruinessen, Martin. "A Nineteenth-century Kurdish Scholar in South Africa." Mullas, Sufis and Heretics: The Role of Religion in Kurdish Society. Collected Articles. Istanbul: The Isis Press, 2000.

Van Selms, Adrianus. Arabies-Afrikaans Studies 1: 'n Tweetalige kategismus. Amsterdam: N.V. Noord Hollansche Uitgevers, 1951.

Wehr, Hans. Arabic-English Dictionary: The Hans Wehr Dictionary of Modern Written Arabic. Ed. John M. Cowan. New York: Spoken Language Services, Inc. 1976. 